\title{
Essential Role for Phosphatidylinositol 4,5-Bisphosphate in the Expression, Regulation, and Gating of the Slow Afterhyperpolarization Current in the Cerebral Cortex
}

\author{
Claudio Villalobos, ${ }^{1}$ Robert C. Foehring, ${ }^{2}$ Jonathan C. Lee, ${ }^{2}$ and Rodrigo Andrade ${ }^{1}$ \\ ${ }^{1}$ Department of Pharmacology, Wayne State University School of Medicine, Detroit, Michigan 48201, and ${ }^{2}$ Department of Anatomy and Neurobiology, \\ University of Tennessee Health Sciences Center, Memphis, Tennessee 38163
}

\begin{abstract}
Many neurons of the CNS and peripheral nervous system express a slow afterhyperpolarization that is mediated by a slow calciumactivated potassium current. Previous work has shown that this aftercurrent regulates repetitive firing and is an important target for neuromodulators signaling through receptors coupled to G-proteins of the $\mathrm{G} \alpha_{\mathrm{q}-11}$ and $\mathrm{G} \alpha_{\mathrm{s}}$ subtypes. Yet, despite considerable effort, a molecular-level understanding of the potassium current underlying the slow afterhyperpolarization and its modulation has proven elusive. Here, we use a combination of pharmacological and molecular biological approaches in cortical brain slices to show that the functional expression of the slow calcium-activated afterhyperpolarizing current in pyramidal cells is critically dependent on membrane phosphatidylinositol 4,5-bisphosphate $\left[\operatorname{Ptd} \operatorname{Ins}(4,5) \mathrm{P}_{2}\right]$ and that this dependence accounts for its inhibition by $5-\mathrm{HT}_{2 \mathrm{~A}}$ receptors. Furthermore, we show that $\operatorname{PtdIns}(4,5) \mathrm{P}_{2}$ regulates the calcium sensitivity of $I_{\mathrm{SAHP}}$ in a manner that suggests it acts downstream from the rise in intracellular calcium. These results clarify key functional aspects of the slow afterhyperpolarization current and its modulation by $5-\mathrm{HT}_{2 \mathrm{~A}}$ receptors and point to a key role for $\operatorname{PtdIns}(4,5) \mathrm{P}_{2}$ in the gating of this current.
\end{abstract}

\section{Introduction}

Many neurons express calcium-activated potassium currents that produce long-lasting afterhyperpolarizations following one or more action potentials. Since the work of Meech and associates in the 1970s (Meech, 1978), these afterhyperpolarizations have been the subject of intense interest because of their ability to regulate repetitive firing and shape how cells encode excitatory inputs into spiking. It is now widely recognized that calcium-activated afterhyperpolarizations involve distinct molecular and kinetic components (Pennefather et al., 1985; Schwindt et al., 1988; Sah and Faber, 2002; Vogalis et al., 2003). In pyramidal cells of the hippocampus and cortex, the early phases of the afterhyperpolarization are mediated by $\mathrm{K}_{\mathrm{Ca}} 1.1$ (BK, Maxi-K) and especially $\mathrm{K}_{\mathrm{Ca}} 2 . \mathrm{X}$ channels, but the mechanism underlying the late phase, generally known as the slow afterhyperpolarization (sAHP) remains ill defined (Sah and Faber, 2002; Vogalis et al., 2003). This is an important gap in our understanding because the sAHP plays an important role in setting the neuronal gain and is regulated by a variety of neuromodulators and thus is thought to play an important role regulating neuronal activity in a variety of brain regions (Nicoll, 1988; Vogalis et al., 2003; Stocker et al., 2004; Higgs et al., 2006).

Received June 22, 2011; revised 0ct. 6, 2011; accepted Nov. 1, 2011.

Author contributions: C.V., R.C.F., and R.A. designed research; C.V., J.C.L., and R.A. performed research; C.V., R.C.F., and R.A. analyzed data; C.V. and R.A. wrote the paper.

This work was supported by NIH Grants MH43985 (R.A.) and NS044163 (R.C.F.). We thank Elaine Weber for excellent technical assistance.

Correspondence should be addressed to Rodrigo Andrade, Department of Pharmacology, Wayne State University School of Medicine, 540 East Canfield Street, Detroit, MI 48201. E-mail: randrade@med.wayne.edu.

DOI:10.1523/JNEUROSCI.3203-11.2011

Copyright $\odot 2011$ the authors $\quad 0270-6474 / 11 / 3118303-10 \$ 15.00 / 0$
Past efforts to understand the mechanism underlying the sAHP have focused on identifying the potassium channel carrying the current underlying this afterpotential $\left(I_{\mathrm{sAHP}}\right)$ and elucidating the mechanism by which calcium gates this current. However, despite substantial work, there is as yet little consensus regarding the properties or identity of the channels carrying $I_{\text {sAHP. }}$ Thus, for example, single-channel analyses have shown remarkable heterogeneity in the properties of putative $I_{\text {sAHP }}$ channels in different cells (Vogalis et al., 2003), while genetic and pharmacological approaches have suggested the involvement of more than one ion channel depending on the cellular background (Tzingounis and Nicoll, 2008). Similarly, although $I_{\text {sAHP }}$ is activated by a rise in intracellular calcium, exactly how this occurs is unclear. The slow rise and slow decay of $I_{\text {sAHP }}$ has been reported to imperfectly track bulk intracellular calcium (Abel et al., 2004), consistent with the recent demonstration that visininlike neuronal calcium sensor proteins can function as a partial calcium sensor for $I_{\text {sAHP }}$ (Tzingounis et al., 2007; Villalobos and Andrade, 2010). These observations can be unified by the suggestion that $I_{\text {sAHP }}$ is gated by calcium acting through an enzymatic cascade (Schwindt et al., 1992; Lasser-Ross et al., 1997). However, how such a mechanism could function has remained unaddressed. Thus, despite substantial progress, neither the channels carrying $I_{\mathrm{sAHP}}$ nor the mechanism through which calcium gates this current are currently known.

\section{Materials and Methods}

Slice preparation. The procedures used for slice preparation were performed in accordance with the U.S. Public Health Service's Policy on Humane Care and Use of Laboratory Animals and were approved by the 
Institutional Animal Care and Use Committees at Wayne State University and the University of Tennessee Health Sciences Center. Recordings were obtained from acute cortical brains slices or cortical brain slices maintained in organotypic culture as previously described (Béique et al., 2007; Yan et al., 2009). Briefly, male rats (Sprague Dawley) or mice [PLC $\beta 1$ knock-out (Kim et al., 1997) or wild-type littermates] of either sex were anesthetized with halothane or isoflurane and killed by decapitation. Slices to be maintained in organotypic culture were prepared from 7- to 12-d-old animals while slices prepared for acute recordings were prepared from 14- to 21-d-old animals. Brains were quickly removed and placed in icecold Ringer's solution of standard composition (in mM: $119 \mathrm{NaCl}, 2.5 \mathrm{KCl}, 1.3 \mathrm{MgSO}_{4}, 2.5$ $\mathrm{CaCl}_{2}, 1 \mathrm{NaH}_{2} \mathrm{PO}_{4}, 26.2 \mathrm{NaHCO}_{3}$, and 11 glucose) supplemented with $10 \mathrm{~mm}$ HEPES and bubbled to saturation with $95 \% \mathrm{O}_{2}$ and $5 \%$ $\mathrm{CO}_{2}$. The anterior pole of the brain was then isolated, affixed to a block with cyanoacrylate glue, and cut using a vibratome (Lancer series 1000; Ted Pella) to produce nominally 300 $\mu \mathrm{m}$-thick coronal brain slices. For the calcium imaging experiments, the slices were prepared using a modified high-sucrose cutting solution containing the following (in $\mathrm{mm}$ ): 250 sucrose, $2.5 \mathrm{KCl}, 1 \mathrm{Na}_{3} \mathrm{PO}_{4}, 11$ glucose, $4 \mathrm{MgSO}_{4}, 0.1$ $\mathrm{CaCl}_{2}, 15$ HEPES. Acute slices were transferred to a holding chamber where they were allowed to recover for at least $1 \mathrm{~h}$ in Ringer's solution. Slices destined for culture were placed on inserts and cultured according to the method of Stoppini et al. (1991) as previously described (Béique et al., 2007).

Electrophysiological recordings. Brain slices were transferred one at a time to a recording chamber on the stage of an upright microscope (Nikon E600FN or Olympus BX50WI) where they were superfused with Ringer's solution bubbled to saturation with $95 \% \mathrm{O}_{2}$ plus $5 \%$ $\mathrm{CO}_{2}$ and maintained at $30 \pm 1^{\circ} \mathrm{C}$. Slices were imaged using differential interference contrast and fluorescence to identify transfected cells. Recordings were obtained from layer $\mathrm{V}$ pyramidal neurons of the prelimbic or anterior cingulate subdivisions of the medial prefrontal cortex (Krettek and Price, 1977). Transfected cells were identified by the expression of either EGFP or mCherry, and recordings from transfected cells in organotypic slices and their controls were conducted 2-7 d after transfection. To compare $I_{\mathrm{sAHP}}$ in transfected and untransfected cells, we recorded from neighboring cells, in most cases as simultaneous and sometimes in sequential recordings, in the same slice to try to minimize variability in the amplitude of $I_{\text {sAHP. }}$. For these experiments, transfected and untransfected cells were separated by no more than $200 \mu \mathrm{m}$ and located at approximately the same cortical depth.

Electrical signals were recorded using AxoClamp 2B, AxoPatch-1D, or Multiclamp 700B amplifiers (Molecular Devices) and digitized and stored in a PC under the control of pClamp 10. Recording pipettes were pulled from borosilicate glass (outer diameter, $1.2 \mathrm{~mm}$ ) using a Flaming-Brown P-97 horizontal puller (Sutter Instrument) to give resistance ranging from 2 to $4 \mathrm{M} \Omega$ when filled with the after breaking into the cell.
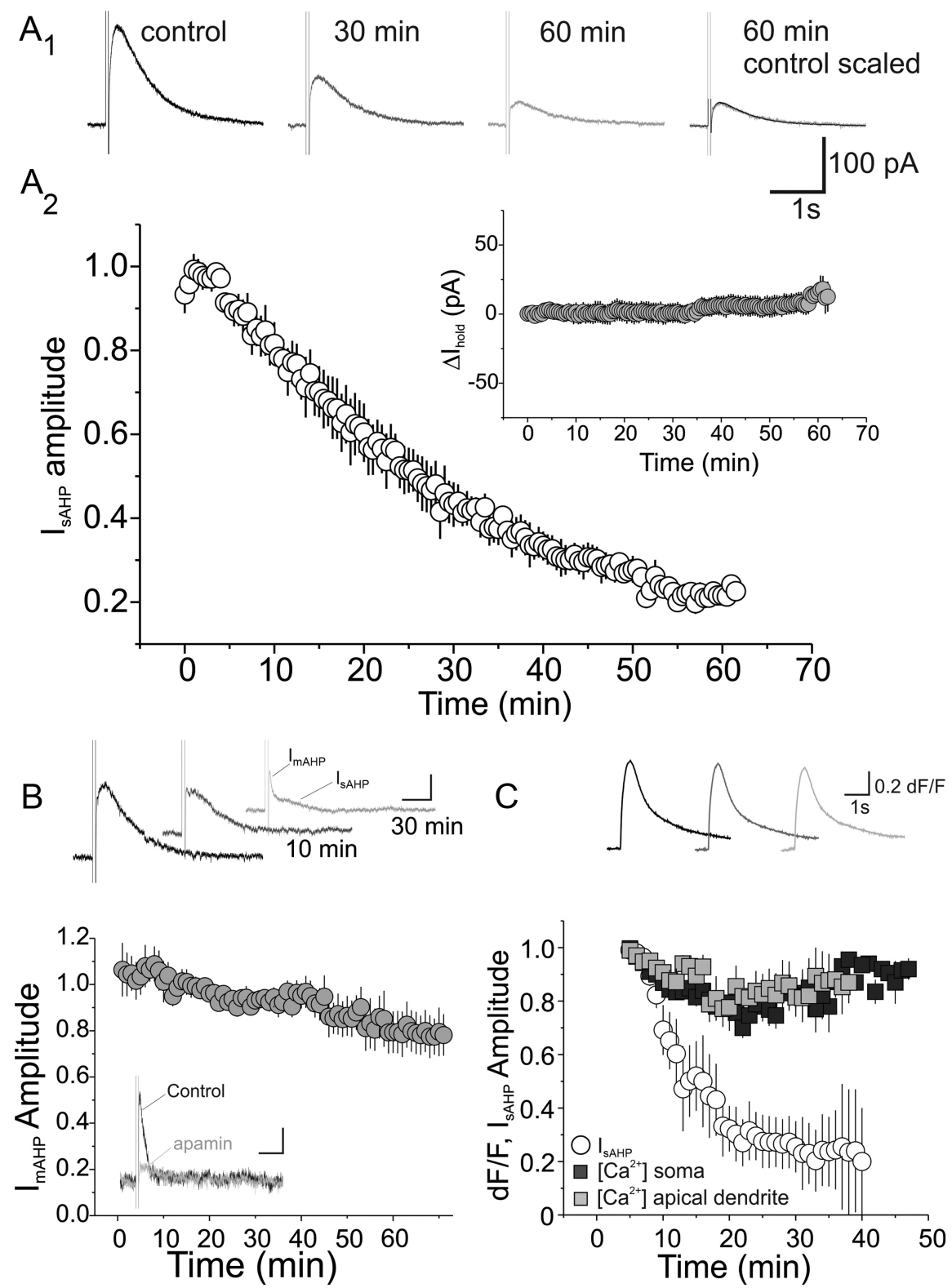

Figure 1. $I_{\text {SAPP }}$ in pyramidal cells of the cerebral cortex runs down upon prolonged whole-cell recording. $A_{1}$, Traces illustrating the rundown of $I_{\text {SAHP }}$ in a pyramidal cell of layer $V$ at varying times after attaining whole-cell access. In this experiment, $300 \mathrm{nM}$ apamin was applied to the slice at the onset to inhibit $I_{\text {mAHP }}$ and isolate $I_{\text {SAHP. }} \cdot A_{2}$, Summary plot illustrating the rundown of $I_{\text {SAHP }}$ in six pyramidal cells. Inset, Summary plot depicting the holding current recorded between measurements of $I_{\text {SAPP }}$ in this same group of cells. Notice that, while $I_{\text {SAHP }}$ runs down over time upon whole-cell recording, the holding current remains stable indicating that the rundown of $I_{\text {SAHP }}$ does not reflect a generalized rundown of channel activity. $\boldsymbol{B}$, In contrast to $I_{\text {SAHP }} I_{\text {mAHP }}$ experiences limited rundown upon prolonged whole-cell recording. The top traces depict the selective rundown of $I_{\text {sAHP }}$ and the relative preservation of $I_{\text {mAHP }}$ in a different cell. Recordings were obtained at $0 \mathrm{~min}$ (black trace), $10 \mathrm{~min}$ (gray trace), and $30 \mathrm{~min}$ (light gray trace). The graph depicts the amplitude of $I_{\text {mAHP }}$ over $1 \mathrm{~h}$ recording in four pyramidal cells of layer V. Inset, Administration of $300 \mathrm{~nm}$ apamin blocks $I_{\text {mAHP. }}$ Calibration: $20 \mathrm{pA}, 1 \mathrm{~s}$. C, Rundown of the $I_{\text {sAHP }}$ is not associated with a concomitant decrease in calcium influx. Pyramidal cells were depolarized to $+20 \mathrm{mV}$ for $100 \mathrm{~ms}$ to open voltage-dependent calcium channels and the resulting $I_{\text {sAHP, }}$ and intracellular calcium transients were measured simultaneously in a group of eight pyramidal cells. Notice that the calcium transients remained generally stable while $I_{\text {sAHP }}$ ran down to $\sim 20 \%$ of its initial value over the course of the recording. Inset, Intracellular calcium transients (100 $\mu \mathrm{m}$ fura-2) recorded at $0 \mathrm{~min}$ (black trace), $10 \mathrm{~min}$ (gray trace), and $30 \mathrm{~min}$ (light gray trace)

appropriate intracellular recording solution. Most recordings were obtained using a potassium-based intracellular solution containing the following (in mM): $130 \mathrm{KMeSO}_{4}, 5 \mathrm{KCl}, 5 \mathrm{NaCl}, 0.02 \mathrm{EGTA}, 1 \mathrm{MgCl}_{2}, 10$ $\mathrm{Na}_{2}$ phosphocreatine, 4 ATP, $0.3 \mathrm{GTP}$, and 11 HEPES, pH 7.3-7.4. After initial characterization of the $I_{\mathrm{sAHP}}$ rundown, this intracellular recording solution was supplemented with $10-30 \mathrm{~mm}$ myo-inositol, a concentra- 

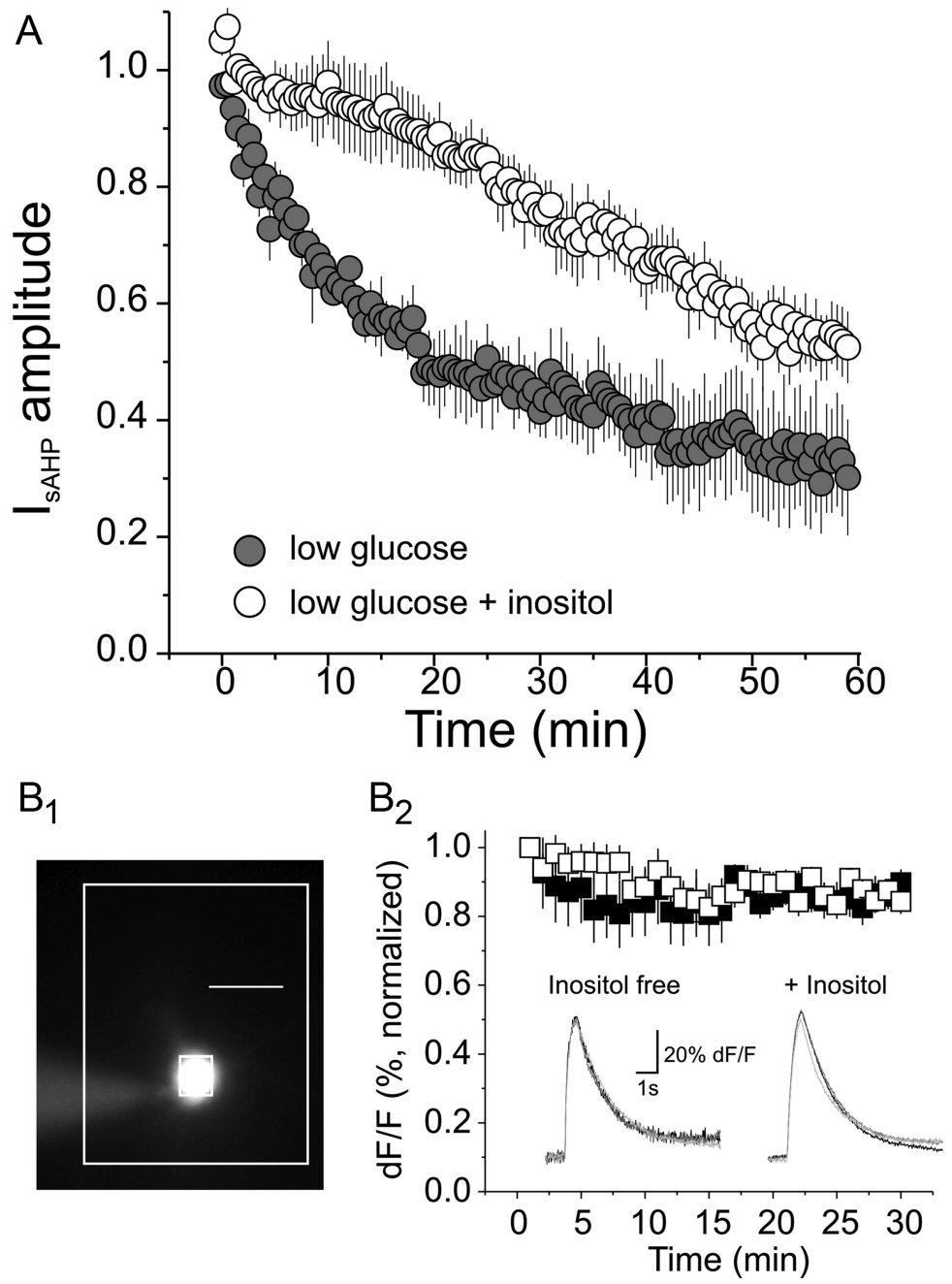

Figure 2. $I_{\text {sAHP }}$ rundown can be slowed down by addition of the inositol precursor myo-inositol to the recording pipette. $A$, Summary graph depicting the rundown of $I_{\text {sAHP }}$ over time in low-glucose extracellular solution ( $5.5 \mathrm{~mm}$; gray circles; $n=4$ cells) and in low-glucose extracellular solution after the addition of $30 \mathrm{~mm}$ myo-inositol to the intracellular recording solution (open circles; $n=5$ cells). $\boldsymbol{B}$, Addition of myo-inositol to the recording solution has no detectable effect on calcium influx after gaining whole-cell access. $\boldsymbol{B}_{1}$, Image illustrating a pyramidal cell filled with the calcium-sensitive dye fura-2 $(100 \mu \mathrm{m})$. Scale bar, $22 \mu \mathrm{m}$. $\boldsymbol{B}_{2}$ Graph depicting the amplitude of the calcium transients recorded under control conditions (no added inositol) and after inclusion of myo-inositol (black squares) in the recording pipette in a group of eight cells. Inset, Calcium transients recorded at 0 $\mathrm{min}$ (black), $10 \mathrm{~min}$ (dark gray), and $30 \mathrm{~min}$ (light gray) after breaking into the cell, with and without myo-inositol in the recording pipette.

tion range that overlaps the estimated intracellular concentration of inositol in central neurons (Fisher et al., 2002). In these experiments, the concentration of $\mathrm{KMeSO}_{4}$ in the intracellular solution was reduced to maintain osmotic equilibrium. For calcium measurements, electrodes were filled with an intracellular recording solution containing the following (in mM): $130.5 \mathrm{KMeSO}_{4}, 10 \mathrm{KCl}, 7.5 \mathrm{NaCl}, 2 \mathrm{MgCl}_{2}, 10$ HEPES, 2 ATP, $0.2 \mathrm{GTP}$, and $100 \mu \mathrm{M}$ fura- 2 pentapotassium salt (Invitrogen). Generally, neurons were held at $-60 \mathrm{mV}$ and $I_{\mathrm{sAHP}}$ was triggered using a 100 -ms-long depolarizing step to $+20 \mathrm{mV}$. $I_{\mathrm{mAHP}}$ and $I_{\mathrm{sAHP}}$ were measured 30-50 and 300-400 ms after the end of the depolarizing step, respectively (Villalobos et al., 2004). In some experiments, apamin (300 nM) was bath-applied to selectively inhibit $I_{\mathrm{mAHP}}$ and isolate $I_{\mathrm{sAHP}}$. Statistical comparisons used $t$ test unless otherwise indicated, and all values are reported as mean \pm SEM.

Calcium imaging. For the calcium imaging experiments, electrical and optical data were collected synchronously using a single computer using a custom Windows-based program (CCD32; written by Dr. J. Callaway, University of Tennessee, Memphis, TN) (Abel et al., 2004). Electrical records were digitized at 16 bit resolution at $10 \mathrm{kHz}$, and corrected for a $10 \mathrm{mV}$ liquid junction potential. Optical recordings were obtained using a Sensicam PCO cooled CCD camera at a frame rate of $50 \mathrm{~Hz}$. Optical data were obtained by exciting the dye $(100 \mu \mathrm{M}$ fura- 2$)$ at a wavelength of $380 \pm 10 \mathrm{~nm}$ and measuring fluorescence changes at an emission wavelength of $520 \pm 40 \mathrm{~nm}$. Changes in fluorescence values were processed and interpreted using a modification of the methods described by Lev-Ram et al. (1992). In this manuscript, we present the data as percentage $\Delta F / F$. Fluorescence measurements were corrected for photobleaching during the trial by measuring the bleaching that occurred when the cell was held hyperpolarized $(-60 \mathrm{mV})$, filtering the resulting curve at $3 \mathrm{~Hz}$, and subtracting the resulting curve from trials in which the cell was depolarized. An autofluorescence correction was performed by subtraction of measured autofluorescence of a nearby region of the slice from the measured initial value of $F$.

Reagents. Drugs were prepared as concentrated stock in $\mathrm{H}_{2} \mathrm{O}$ and kept frozen. They were thawed immediately before the experiment and administered to the slice dissolved in the Ringer's at known concentrations. Most drugs were obtained from Sigma-Aldrich. TTX was obtained from EMD Biosciences, and $(R)-(+)-\alpha-(2,3-$ dimethoxyphenyl)-1-[2-(4-fluorophenyl)ethyl]4-piperidinemethanol (MDL100907) was a kind gift from Dr. Kenner Rice (Laboratory of Medicinal Chemistry, NIDDK, Bethesda, MD). EGFPtagged PIP5K $\gamma 90$ and PIP5K $\gamma 93$ (Giudici et al., 2004, 2006) were kinds gifts from Drs. M. L. Giudici and R. F. Irvine (University of Cambridge, Cambridge, UK) and PLC- $\delta$ PH (Stauffer et al., 1998) was a kind gift from Dr. T. Meyer (Stanford University, Stanford, CA). Mouse INPP5b in pCMV-Sport6 was obtained from the NIH Mammalian Genome Collection (IMAGE ID 4457437; ATCC catalog\#10324723).

\section{Results}

Rundown of $I_{\text {sAHP }}$ upon prolonged whole-cell recordings

Pyramidal cells of layer $\mathrm{V}$ of the prefrontal cortex express an $I_{\text {sAHP }}$ that can be triggered using a brief depolarizing step capable of activating voltage-gated calcium channels to allow calcium influx into the cell (Fig. $1 A_{1}$ ). A prominent feature of this $I_{\text {sAHP }}$ recorded in the whole-cell configuration is that it runs down over time (Fig. $1 A_{2}$ ). As illustrated in Figure $1 \mathrm{~A}$, under our recording conditions, $I_{\text {sAHP }}$ decreases by nearly $80 \%$ within $1 \mathrm{~h}$ of recording without any obvious change in its time course (Fig. $1 A_{1}$ ) or the holding current of the cell (Fig. $1 A_{2}$, inset).

Since $I_{\text {sAHP }}$ is a calcium-activated current, the rundown could simply reflect decreased calcium influx secondary to the rundown of calcium currents. We first assessed this possibility by examining the rundown of $I_{\mathrm{mAHP}}$, a second calcium-activated potassium current carried by $\mathrm{K}_{\mathrm{ca}} 2 . \mathrm{x}$ (SK) channels that is also expressed in these pyramidal cells (Villalobos et al., 2004). As illustrated in Figure $1 B$, top traces, $I_{\text {sAHP }}$ runs down much more rapidly than $I_{\mathrm{mAHP}}$ in pyramidal cells expressing both $I_{\mathrm{mAHP}}$ and $I_{\text {sAHP. }}$ Because the time courses of these currents overlap, it was difficult to quantify the rundown of $I_{\mathrm{mAHP}}$ in isolation. Therefore, we examined the rundown of $I_{\mathrm{mAHP}}$ in pyramidal cells ex- 
pressing small $I_{\text {sAHP }}$ values. As illustrated in Figure $1 B$, graph, the amplitude of $I_{\text {mAHP }}$ remains relatively stable over nearly $1 \mathrm{~h}$ of whole-cell recording, a time frame during which $I_{\text {sAHP }}$ undergoes near complete rundown. This suggested limited rundown of calcium currents and calcium influx under our recording conditions. To test for changes in calcium influx, we additionally conducted calcium imaging experiments using fura-2 while simultaneously recording $I_{\text {sAHP }}$ (Abel et al., 2004). As illustrated in Figure $1 C$, under our recording conditions, somatic and dendritic fura-2 transients, which are proportional to changes in calcium concentration, remained stable over nearly an hour of whole recording. In contrast, $I_{\text {sAHP }}$ recorded simultaneously again exhibited very substantial rundown. These experiments show a clear dissociation between the rundown of $I_{\text {sAHP }}$ and changes in fura$2 /$ calcium transients and thus do not support the idea that the rundown of $I_{\mathrm{sAHP}}$ is simply secondary to the rundown of calcium currents.

\section{Facilitating phosphatidylinositol}

4,5-bisphosphate biosynthesis protects $I_{\text {sAHP }}$ from rundown

The activity of a number of ion channels, including many potassium channels, depends on membrane phosphatidylinositol 4,5-bisphosphate $\left[\operatorname{PtdIns}(4,5) \mathrm{P}_{2}\right]$, and the loss of PtdIns $(4,5) \mathrm{P}_{2}$ results in the rundown of these currents (for review, see Rohacs et al., 2002). These observations raised the possibility that the rundown of $I_{\text {sAHP }}$ observed in pyramidal neurons of the prefrontal cortex could similarly involve loss of membrane PtdIns $(4,5) \mathrm{P}_{2}$. To test this conjecture, we took advantage of the previous demonstration that membrane PtdIns $(4,5) \mathrm{P}_{2}$ levels can be effectively manipulated in intact cells by regulating its synthesis and degradation (Suh and Hille, 2002; Zhang et al., 2003; Li et al., 2005).

In a first series of experiments, we facilitated $\operatorname{PtdIns}(4,5) \mathrm{P}_{2}$ biosynthesis by increasing intracellular inositol, which is the obligatory starting substrate for the synthesis of $\operatorname{PtdIns}(4,5) \mathrm{P}_{2}$. For these experiments, we minimized de novo inositol biosynthesis by reducing extracellular glucose from 11 to $5.5 \mathrm{~mm}$ while maintaining intracellular ATP levels by including Mg-ATP plus phosphocreatine in the recording solution. Low glucose accelerated the early phase of the rundown and also made it more consistent from cell to cell. Intracellular perfusion of myo-inositol at concentrations close to those estimated to be present in central neurons (Fisher et al., 2002) resulted in significant protection of $I_{\text {sAHP }}$ from rundown (Fig. 2). Overall, in this experiment, $I_{\mathrm{sAHP}}$ was found to decay to $42 \pm 4.3 \%$ of its initial amplitude within $30 \mathrm{~min}$ in the absence of inositol but remained at $80 \pm 1.3 \%$ of its initial amplitude in the presence of inositol $(p<0.01)$.
While these results supported the idea that the rundown of $I_{\text {sAHP }}$ involved impaired inositol metabolism, it remained possible that inositol could protect $I_{\text {sAHP }}$ indirectly, by increasing calcium influx. Therefore, we again imaged intracellular calcium transients as a function of time in the presence and absence of myo-inositol added to the intracellular solution. As illustrated in Figure $2 B$, we could not detect any significant differences in calcium influx in response to intracellular perfusion of myoinositol. These results argued against a possible indirect effect on calcium entry and pointed to a direct effect of inositol on the stability of $I_{\text {sAHP. }}$.

Because the addition of inositol to the intracellular solution afforded only partial protection from the rundown, we used particle-mediated gene transfer (biolistic or "gene gun") to additionally overexpress the PtdIns $(4,5) \mathrm{P}_{2}$ synthetic enzyme phosphatidylinositol 4-phosphate 5-kinase (PIP5K). In mammals, PIP5K activity is mediated by three isoforms, PIP5KI $\alpha, \mathrm{PIP} 5 \mathrm{KI} \beta$, and PIP5KI $\gamma$, which are thought to be responsible for the synthe- 

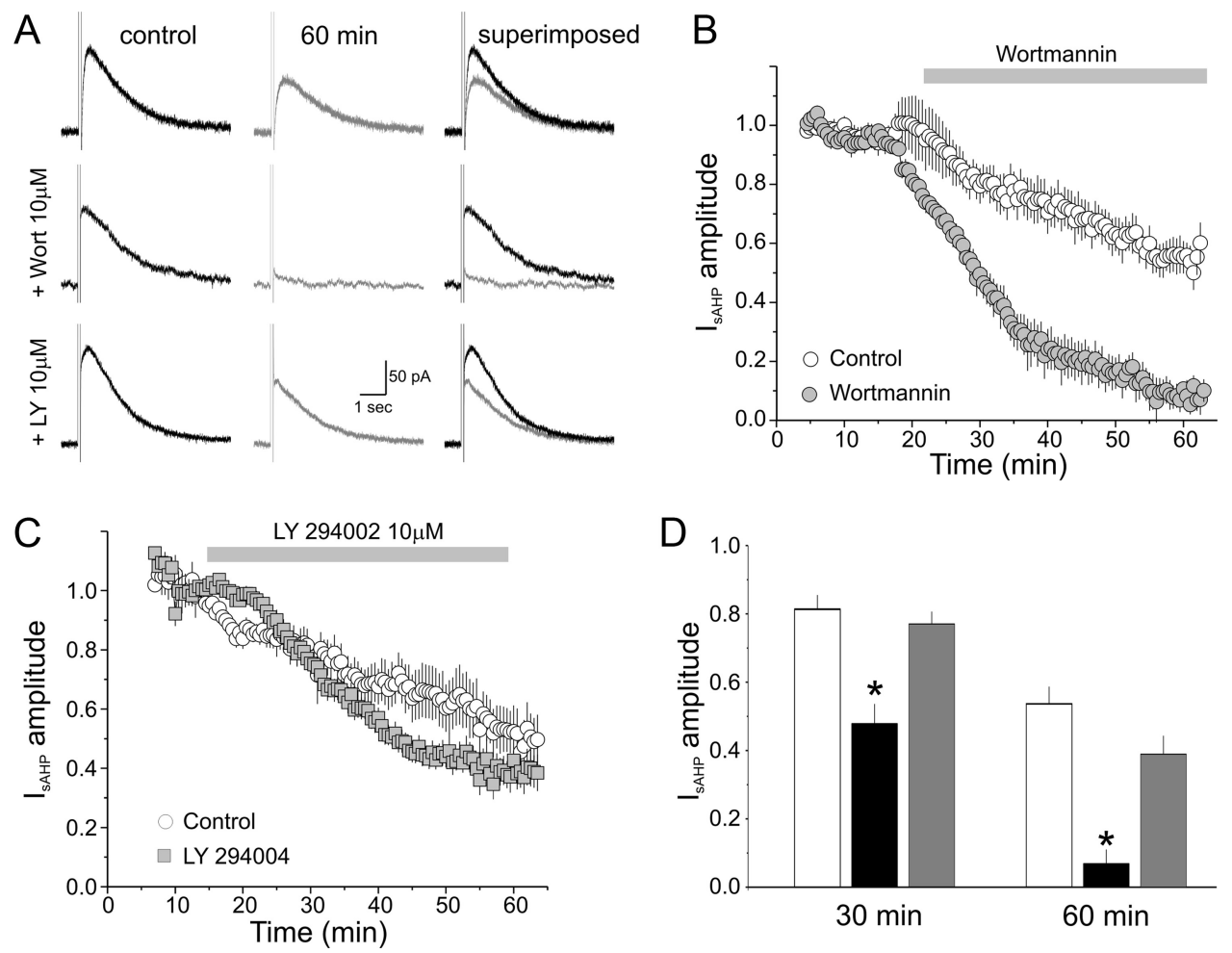

Figure 4. Wortmannin, but not LY 294002, accelerates the rundown of $I_{\text {sAHP. }} . A$, Effect of wortmannin $(10 \mu \mathrm{M})$ or LY $294002(10 \mu \mathrm{M})$ on the rundown of $I_{\text {sAHP. }}$, P Plot summarizing the effect of wortmannin on the rundown of $I_{\text {sAHP. }}$. Control, $n=6$ cells; wortmannin, $n=5$ cells. All these experiments were conducted with inositol in the intracellular solution. C, Plot summarizing the effect of $\mathrm{LY} 294002$ on the rundown of $I_{\text {SAHP }}$ (control, $n=9$ cells; LY 294002, $n=17$ cells). $D$, Comparison of the amplitude of $I_{\text {sAHP }}$ under control conditions, in the presence of wortmannin and in the presence of $L Y 29400230$ and 60 min after gaining whole-cell access. ${ }^{*} p<0.005$. Error bars indicate SEM. For all the graphs in this figure, the amplitude of $I_{\text {SAHP }}$ was normalized to the initial value measured shortly after gaining whole-cell access. All recordings for this experiment included myo-inositol in the recording pipette.

sis of most cellular PtdIns $(4,5) \mathrm{P}_{2}$. Among these enzymes, the $\gamma$ isoform shows the strongest expression in the brain including the cerebral cortex (Akiba et al., 2002) and has been shown to be primarily responsible for the synthesis of $\operatorname{PtdIns}(4,5) \mathrm{P}_{2}$ in the brain (Volpicelli-Daley et al., 2010). Therefore, for these experiments, we expressed two alternative spliced isoforms of PIP5K $\gamma$ (PIP5K $\gamma 90$ or PIP5K $\gamma 93$ ) tagged with GFP (Giudici et al., 2006). Biolistic transfection of either of these enzyme isoforms into pyramidal cells in organotypic brain slices (Villalobos et al., 2004; Béique et al., 2007) resulted in strong expression of the fused protein, as visualized by the EGFP fluorescence, which localized predominantly to the plasma membrane including fine dendritic processes (Fig. $3 A$ ). To test the effect of facilitating $\operatorname{PtdIns}(4,5) \mathrm{P}_{2}$ biosynthesis on $I_{\text {sAHP }}$, we conducted paired recordings from transfected and neighboring untransfected neurons. Since expression of EGFP alone has no effect on $I_{\text {sAHP }}$ (Yan et al., 2009), this approach was preferred to mock transfections because it controls more stringently for cell location and slice history. As illustrated in Figure 3, $B$ and $C$, expression of PIP5K $\gamma 90$ or PIP5K $\gamma 93$ in conjunction with the addition of intracellular inositol greatly protected $I_{\text {sAHP }}$ from rundown, especially at late times in the experiment (Fig. $3 B, C$ ). Together, these experiments show that manipulations that facilitate $\operatorname{PtdIns}(4,5) \mathrm{P}_{2}$ biosynthesis protect $I_{\text {sAHP }}$ from rundown.

\section{Inhibition of PtdIns $(4,5) \mathrm{P}_{2}$ biosynthesis accelerates the rundown of $I_{\text {sAHP }}$}

If the functional expression of $I_{\mathrm{sAHP}}$ depends on membrane $\operatorname{PtdIns}(4,5) \mathrm{P}_{2}$, then inhibiting the synthesis of this phosphoinositide should accelerate the rundown of $I_{\text {sAHP }}$ (Suh and Hille,
2002). To test this idea, we first used the lipid kinase inhibitor wortmannin to inhibit PtdIns $(4,5) \mathrm{P}_{2}$ biosynthesis (Nakanishi et al., 1995; Meyers and Cantley, 1997). As illustrated in Figure 4, A and $B$, bath application of wortmannin $(10 \mu \mathrm{M})$ significantly accelerated the rundown of $I_{\text {sAHP }}$. Thus, in these experiments, the amplitude of $I_{\mathrm{sAHP}}$ remained at $80 \pm 6.0 \%$ of its initial amplitude after $30 \mathrm{~min}$ in the control cells while it decreased to $49 \pm 4.4 \%$ of its initial value in the presence of wortmannin $(p<0.005$; Fig. $4 D)$. Within the phosphoinositide synthetic pathway, wortmannin not only inhibits the synthesis of $\operatorname{PtdIns}(4,5) \mathrm{P}_{2}$ but also of PtdIns $(3,4,5) \mathrm{P}_{3}$ by inhibiting phosphoinositide 3-kinase (PI3K). Therefore, to control for this activity, we also tested the effect of the selective PI3K inhibitor 2-(4-morpholinyl)-8-phenyl-4 H-1benzopyran-4-one (LY 294002) on the rundown of $I_{\text {sAHP. }}$ As illustrated in Figure 4, $A$ and $C$, administration of LY 294002 (10 $\mu \mathrm{M})$ had no significant effect on the rundown of $I_{\text {sAHP. }}$. Thus, in this experiment, the amplitude of $I_{\text {sAHP }}$ after $30 \mathrm{~min}$ of whole-cell recording averaged $77 \pm 5.2 \%$ of its initial value under control conditions and $75 \pm 3.8 \%$ in the presence of LY 294002 ( $p=$ 0.49 ; Fig. $4 D$ ). As an additional control, we again simultaneously recorded $I_{\text {sAHP }}$ and imaged calcium transients in response to depolarizing voltage steps in the presence and absence of wortmannin. In these experiments, wortmannin again accelerated the rundown of $I_{\text {sAHP }}$ but had little effect on the amplitude of the calcium transients ( $n=7 ; p=0.8$; data not shown).

While these experiments again supported the idea that the functional expression of $I_{\text {sAHP }}$ depended on $\operatorname{PtdIns}(4,5) \mathrm{P}_{2}$, they were limited by broad activity of wortmannin against a variety of kinases. Therefore, we sought more specific approaches to reduce the availability of membrane $\operatorname{PtdIns}(4,5) \mathrm{P}_{2}$. In an additional set 
of experiments, we again used particlemediated gene transfer to express the mouse enzyme 5-phosphatase II/Inpp5b, which dephosphorylates $\operatorname{PtdIns}(4,5) \mathrm{P}_{2}$ and thus reduces its membrane concentration (Li et al., 2005). This 5-phosphatase was chosen because, among known $5^{\prime}$-phosphatases, this isoform is well expressed in the brain, including the cerebral cortex (Allen Brain Atlas). To test the effect of the 5-phosphatase on $I_{\text {sAHP }}$, we again conducted paired recordings from transfected and neighboring untransfected cells $2 \mathrm{~d}$ after transfection. As illustrated in Figure $5 A$, expression of 5-phosphatase II/Inpp5b resulted in a significant reduction in the amplitude of $I_{\text {sAHP }}(p<0.05)$. Importantly, expression of the phosphatase had no significant effect on the amplitude of $I_{\mathrm{mAHP}}$, indicating that the inhibition of $I_{\mathrm{SAHP}}$ was unlikely to simply reflect a decrement in calcium channel functioning (control, $99 \pm 18 \mathrm{pA}$; 5-phosphatase II/Inpp5b, $105 \pm 61 \mathrm{pA}$; $p=0.94$; Fig. $4 A$, inset).

In a second set of experiments, we examined the effect of sequestering PtdIns $(4,5) \mathrm{P}_{2}$ on $I_{\text {sAHP }}$ using the $\mathrm{PH}$ domain of phospholipase C- $\delta 1$ fused to GFP (PLC$\delta \mathrm{PH})$ (Stauffer et al., 1998). Previous studies have shown that this construct selectively binds and sequesters membrane PtdIns $(4,5) \mathrm{P}_{2}$, making this phosphoinositide unavailable to the ion channels ( $\mathrm{Li}$ et al., 2005). As illustrated in Figure 5B, expression of the PLC- $\delta \mathrm{PH}$ in pyramidal cells resulted in a significant reduction in the amplitude of the $I_{\text {sAHP }}$ when compared with neighboring control untransfected cells. Again, expression of this construct had no significant effect on the amplitude of $I_{\mathrm{mAHP}}$ (Fig. $5 B$, inset; control, $65 \pm 9$ pA; PLC- $\delta$ PH, $55 \pm 7 \mathrm{pA} ; p=$ $0.2)$. Combined, these results indicated that the functional expression of $I_{\text {sAHP }}$ depends on the availability of membrane $\operatorname{PtdIns}(4,5) \mathrm{P}_{2}$.

$5-\mathrm{HT}_{2 \mathrm{~A}}$ receptors inhibit $I_{\text {sAHP }}$ by signaling the breakdown of PtdIns $(4,5) \mathrm{P}_{2}$

As noted in the Introduction, activation of heptahelical receptors coupling to heterotrimeric G-proteins of the $\mathrm{G} \alpha_{\mathrm{q}-11}$ subtype inhibit $I_{\text {sAHP }}$ in many cell types (Nicoll, 1988; Krause et al., 2002; Villalobos et al., 2005). Since such receptors elicit the breakdown of PtdIns $(4,5) \mathrm{P}_{2}$ through the activation of phospholipase $\mathrm{C} \beta$, the results outlined above suggest a ready mechanism for such an inhibition (Suh and Hille, 2002; Delmas and Brown, 2005; Li et al., 2005; Logothetis et al., 2007). To test this possibility, we took advantage of our previous demonstration that serotonin receptors of the 5- $\mathrm{HT}_{2 \mathrm{~A}}$ subtype, which couple to heterotrimeric G-proteins of the $\mathrm{G} \alpha_{\mathrm{q}-11}$ subtype, strongly inhibit $I_{\text {sAHP }}$ in pyramidal cells of the anterior cerebral cortex (Villalobos et al., 2005).

\section{A 5-phosphatase}
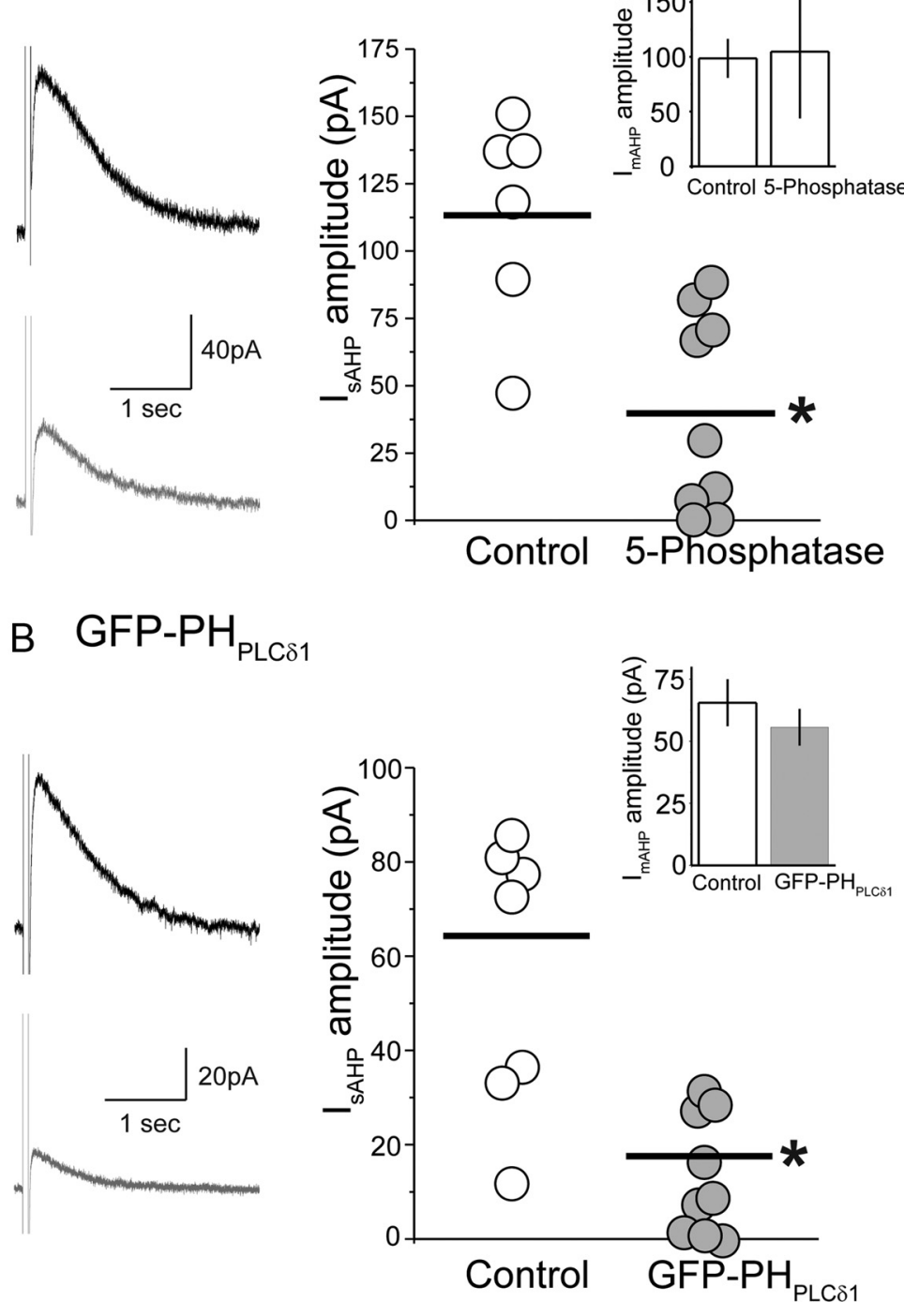

Figure 5. Expression of a 5-phosphatase or a $\operatorname{Ptd} \operatorname{lns}(4,5) \mathrm{P}_{2}$ sequestering construct inhibit $I_{\text {sAHP. }} A$, Transfection of 5 -phosphatase II/InPP5B into pyramidal cells in organotypic brain slices reduces $I_{\text {sAHP }}$ amplitude. Left traces illustrate $I_{\text {sAHP }}$ recorded from neighboring 5-phosphatase II-transfected (green) and untransfected (black) pyramidal cells $2-3 \mathrm{~d}$ after transfection. thraph summarizes the effect of expressing the 5 -phosphatase II on $I_{\text {SAHP }}$ in nine transfected and six control neurons. $p<$ PLC $\delta$ fused to EGFP (GFP-PH $H_{\text {PLC } 11}$ ), which sequesters Ptdlns $(4,5) \mathrm{P}_{2}$, reduces $I_{\text {sAHP. }}$. Left traces illustrate $I_{\text {sAHP }}$ recorded from a Right graph summarizes the results obtained in seven transfected and six control neurons. $p<0.05$. The inset compares the effect of expressing GFP-PH $\mathrm{PLC} \delta_{1} 1$ on $I_{\text {mAHP }}$ in this same group of cells.

Because $5-\mathrm{HT}_{2 \mathrm{~A}}$ receptors can potentially signal through multiple parallel biochemical cascades (Berg et al., 1998; Williams et al., 2007), we first asked whether the ability of $5-\mathrm{HT}_{2 \mathrm{~A}}$ receptors to inhibit $I_{\text {sAHP }}$ requires PLC $\beta$. PLC $\beta 1$ is the predominant PLC $\beta$ isoform expressed in the cerebral cortex (Watanabe et al., 1998); therefore, we examined the ability of the preferential $5-\mathrm{HT}_{2 \mathrm{~A}}$ receptor agonist $\alpha$-methyl-serotonin to inhibit $I_{\mathrm{sAHP}}$ in PLC $\beta 1$ knock-out mice (Kim et al., 1997). Consistent with previous findings, administration of $\alpha$-methyl-serotonin to wild-type mice inhibited $I_{\text {sAHP }}$ and induced the appearance of a slow afterdepolarization (Araneda and Andrade, 1991; Villalobos et al., 2005). In contrast, administration of $\alpha$-methyl-serotonin to PLC $\beta 1$ knock-out mice had little if any effect on $I_{\text {sAHP }}$ in most 

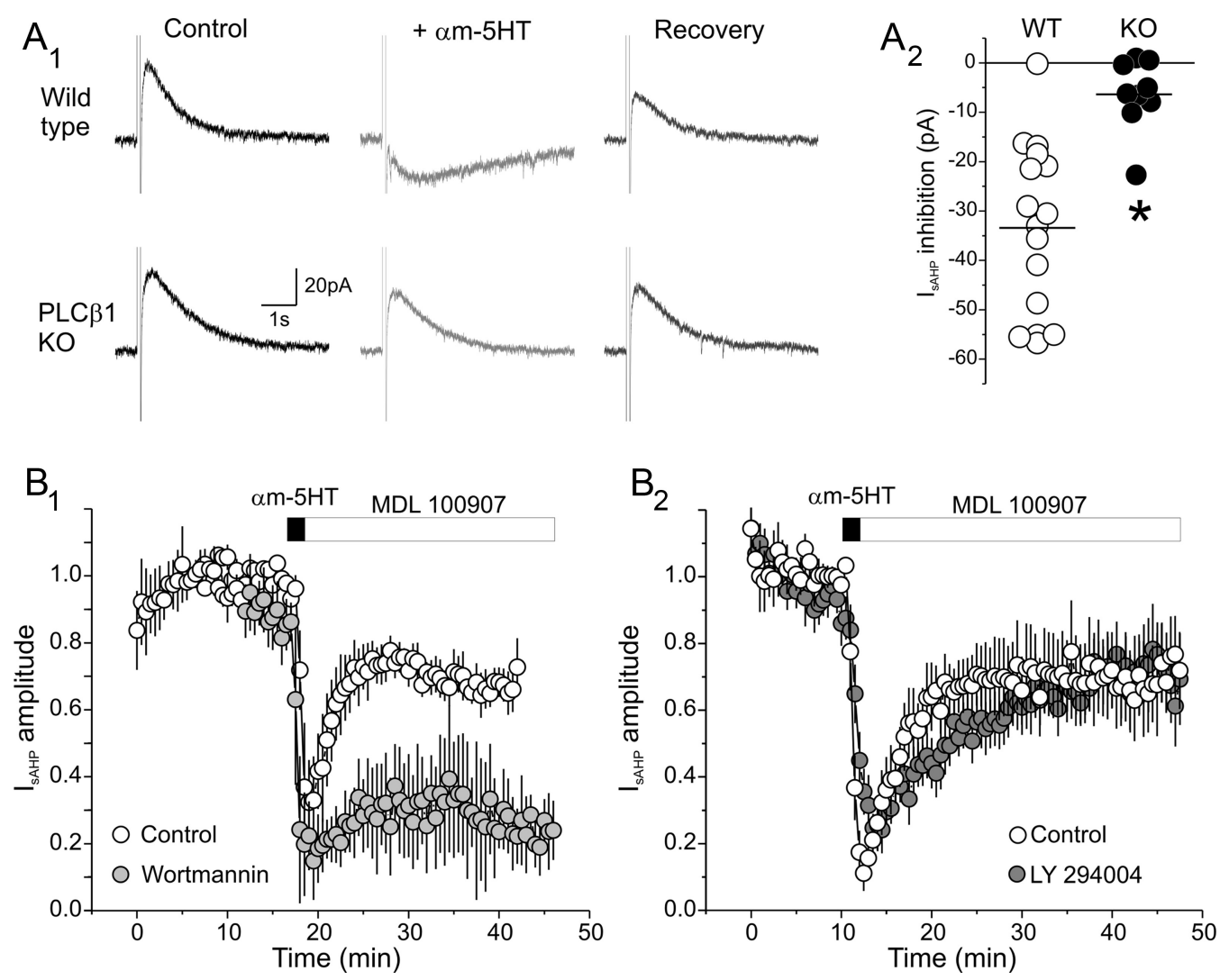

Figure 6. $5-\mathrm{HT}_{2 \mathrm{~A}}$ receptors inhibit $I_{\mathrm{sAHP}}$ by signaling the breakdown of $\operatorname{Ptdlns}(4,5) \mathrm{P}_{2} \cdot A_{1}$, Inhibition of $I_{\text {sAHP }}$ by $30 \mu \mathrm{m} \alpha$-methyl-5-HT in pyramidal cells in cortical slices derived from wild-type or PLC $\beta 1$ knock-out mice. $A_{2}$, Graph summarizing the effect of $30 \mu \mathrm{m} \alpha$-methyl-5-HT on the amplitude of $\mathrm{I}_{\text {sAHP }}$ in 9 pyramidal cells in slices derived from PLC $\beta 1 \mathrm{knock}$-out mice and 16 pyramidal cells in slices derived from their wild-type littermates. ${ }^{*} p<0.05 . B_{1}$, Effect of wortmannin $(10 \mu \mathrm{m})$ on the time course of $I_{\text {sAHP }}$ inhibition elicited by $10 \mu \mathrm{m} \alpha$-methyl-5-HT. The presence of wortmannin in the bath is indicated by the gray circles ( $n=4$ cells). $\boldsymbol{B}_{2}$, Effect of $\mathrm{LY} 294002(10 \mu \mathrm{M})$ on the time of $I_{\text {sAHP }}$ inhibition by $10 \mu \mathrm{m} \alpha$-methyl-5-HT. The gray circles denote the presence of $\mathrm{LY} 294002$ in the bath (control, $n=5$ cells; LY, $n=6$ cells). In both of these experiments, the selective $5-\mathrm{HT}_{2 \mathrm{~A}}$ receptor antagonist MDL100907 (1 $\mu \mathrm{M}$ ) was added immediately after $\alpha$-methyl-5-HT to terminate $5-\mathrm{HT}_{2 \mathrm{~A}}$ receptor stimulation.

cells tested (Fig. 6A). These results indicated that the ability of $5-\mathrm{HT}_{2 \mathrm{~A}}$ receptors to inhibit $I_{\mathrm{sAHP}}$ is dependent on the functional expression of PLC $\beta 1$ and thus also the ability to elicit the breakdown of PtdIns $(4,5) \mathrm{P}_{2}$.

To test the idea that $5-\mathrm{HT}_{2 \mathrm{~A}}$ receptors inhibit $I_{\mathrm{sAHP}}$ by reducing membrane PtdIns $(4,5) \mathrm{P}_{2}$ levels, we again took advantage of the ability of wortmannin to inhibit PI4K and hence block the resynthesis of this phosphoinositide after activation of PLC $\beta$. If $5-\mathrm{HT}_{2 \mathrm{~A}}$ receptors inhibit $I_{\mathrm{sAHP}}$ by lowering the availability of membrane PtdIns $(4,5) \mathrm{P}_{2}$, then wortmannin but not LY 294002 should render the 5- $\mathrm{HT}_{2 \mathrm{~A}}$ receptor-signaled inhibition of $I_{\mathrm{sAHP}}$ effectively irreversible (Suh and Hille, 2002). To test this idea, we activated $5-\mathrm{HT}_{2 \mathrm{~A}}$ receptors using $\alpha$-methyl-serotonin and rapidly terminated its effect by applying the $5-\mathrm{HT}_{2 \mathrm{~A}}$ receptor antagonist MDL100907 $(1 \mu \mathrm{M})$. As illustrated in Figure $6 B_{1}$, under control conditions the $\alpha$-methyl-serotonin-induced inhibition of $I_{\mathrm{sAHP}}$ exhibited a rapid recovery, but this inhibition became essentially irreversible in the presence of wortmannin $(10 \mu \mathrm{M}$; Fig. $6 B_{1}$ ). In contrast, when this experiment was repeated using LY 294004 instead of wortmannin, the recovery of $I_{\text {sAHP }}$ was indistinguishable from control. These results support the idea that $5-\mathrm{HT}_{2 \mathrm{~A}}$ receptors inhibit $I_{\mathrm{sAHP}}$ by activating PLC $\beta$ and reducing membrane PtdIns $(4,5) \mathrm{P}_{2}$.

PtdIns(4,5) $\mathrm{P}_{2}$ regulates the calcium sensitivity of $I_{\mathrm{sAHP}}$ PtdIns $(4,5) \mathrm{P}_{2}$ plays an essential role in the gating of a variety of potassium channels [Hansen et al. (2011) and references therein]. For example, $G \beta \gamma$ gates Kir3 channels by stabilizing the interaction of PtdIns $(4,5) \mathrm{P}_{2}$ with the channel (Huang et al., 1998). Similarly, the potassium channel auxiliary subunit KCNE1 facilitates KCNQ1 currents in the heart by increasing the affinity of the channel for PtdIns(4,5) $\mathrm{P}_{2}$ (Li et al., 2011). Thus, one possible interpretation of the results above is that $\operatorname{PtdIns}(4,5) \mathrm{P}_{2}$ is required downstream from calcium to activate $I_{\mathrm{sAHP}}$. If that was the case, it could be expected that increasing the concentration of $\operatorname{PtdIns}(4,5) \mathrm{P}_{2}$ should facilitate the ability of calcium to activate this current. To test this idea, we again overexpressed PIP5K, a manipulation previously shown to increase membrane PtdIns(4,5) $\mathrm{P}_{2}$ (Li et al., 2005; Suh et al., 2006), and examined the calcium sensitivity of $I_{\mathrm{SAHP}}$.

To assess the calcium dependence of $I_{\mathrm{sAHP}}$, we took advantage of the previous demonstration that the calcium-triggering $I_{\mathrm{sAHP}}$ enters the cell through voltage-activated calcium channels. As a result, depolarizing steps of increasing amplitude or duration can be used to elicit graded increases in calcium that lead to progressive activation of $I_{\mathrm{sAHP}}$ (Villalobos and Andrade, 2010). As illustrated in Figure $7 A$, under our recording conditions 10 - to 100 -ms-long depolarizing steps to $+20 \mathrm{mV}$ result in graded activation of $I_{\mathrm{SAHP}}$ amplitude with little further activation with longer steps (Fig. $7 B$ ). Expression of either PIP5K $\gamma 90$ or PIP5K $\gamma 93$ had no detectable effect on the maximal amplitude of $I_{\mathrm{sAHP}}$ determined using 100 long depolarizing steps (control, $58 \pm 6 \mathrm{pA}$; PIP5K, $56 \pm 3 \mathrm{pA}$ ) but resulted in a large increase in the apparent calcium sensitivity of $I_{\mathrm{sAHP}}$ (Fig. $7 \mathrm{~A}$ ). Thus, in cells 
transfected with PIP5K, $I_{\mathrm{sAHP}}$ was maximally activated by 10 - to 20 -ms-long depolarizing steps, which correspond to step durations near threshold for activating $I_{\mathrm{sAHP}}$ under control conditions, and appeared saturated through the rest of the control activation range (Fig. 7A). This facilitation was seen most dramatically when using depolarizing steps in the 1-10 ms range, which under control conditions elicit little or no $I_{\mathrm{SAHP}}$ but produce robust graded increases in $I_{\mathrm{SAHP}}$ amplitude in cells transfected with PIP5K (Fig. 7C,D). In contrast to the dramatic effects of overexpressing PIP5K on the activation of $I_{\text {sAHP }}$, we observed no difference in the activation of $I_{\mathrm{mAHP}}$ (Fig. $7 A$, inset). This argues against the possibility that these changes could simply reflect changes in calcium influx. Together, these results support the idea $\operatorname{PtdIns}(4,5) \mathrm{P}_{2}$ acts downstream from calcium in the gating of $I_{\mathrm{SAHP}}$.

\section{Discussion}

The slow calcium-activated afterhyperpolarization generated by $I_{\mathrm{sAHP}}$ has long been recognized as an important regulator of neuronal excitability in many neuronal cell types. However, despite considerable effort, the molecular basis underlying $I_{\mathrm{sAHP}}$, the mechanism through which it is gated by calcium, and how this current is regulated by heptahelical receptors remain poorly understood. In the current work, we show that the functional expression and gating of $I_{\mathrm{sAHP}}$ in cortical pyramidal neurons is dependent on membrane $\operatorname{PtdIns}(4,5) \mathrm{P}_{2}$ and that $5-\mathrm{HT}_{2 \mathrm{~A}}$ receptors inhibit this aftercurrent by activating $\operatorname{PLC} \beta$ and reducing membrane PtdIns $(4,5) \mathrm{P}_{2}$ levels.

The first hint that $I_{\text {sAHP }}$ could be regulated by $\operatorname{PtdIns}(4,5) \mathrm{P}_{2}$ emerged from the observation that this current runs down upon prolonged whole-cell recording. A similar rundown has been seen for other potassium currents, such as those carried by $\mathrm{K}_{\mathrm{ir}}$ and $\mathrm{K}_{\mathrm{v}} 7$ channels. In those cases, the rundown has been shown to result from depletion of membrane $\operatorname{PtdIns}(4,5) \mathrm{P}_{2}$ during prolonged whole-cell recording (Logothetis et al., 2007; Rohacs, 2009), which compromises the ability of the cell to synthesize PtdIns $(4,5) \mathrm{P}_{2}$. Consistent with the possible involvement of such a mechanism, the rundown of $I_{\text {sAHP }}$ was suppressed by manipulations that facilitate $\operatorname{PtdIns}(4,5) \mathrm{P}_{2}$ biosynthesis, such as increasing the availability of inositol or expressing of the synthetic enzyme PIP5K, and conversely was accelerated by pharmacological inhibition of PtdIns $(4,5) \mathrm{P}_{2}$ biosynthesis. Equally important, decreasing the concentration of membrane $\operatorname{PtdIns}(4,5) \mathrm{P}_{2}$ by expressing a $5^{\prime}$-phosphatase or sequestering this phospholipid by expressing the PH domain of PLC $\delta 1$ both resulted in profound suppressions of $I_{\mathrm{sAHP}}$. These converging results lead us to conclude that the functional expression of $I_{\mathrm{sAHP}}$ depends on the availability of $\operatorname{PtdIns}(4,5) \mathrm{P}_{2}$ at the plasma membrane.

One potential confound of the above experiments is that $I_{\mathrm{SAHP}}$ is triggered by calcium influx, and calcium channel activity itself has been shown to be dependent on membrane $\operatorname{PtdIns}(4,5) \mathrm{P}_{2}$ (Delmas et al., 2005). However, changes in $I_{\text {sAHP }}$ were clearly dissociable from changes in $I_{\mathrm{mAHP}}$, a second calcium-activated
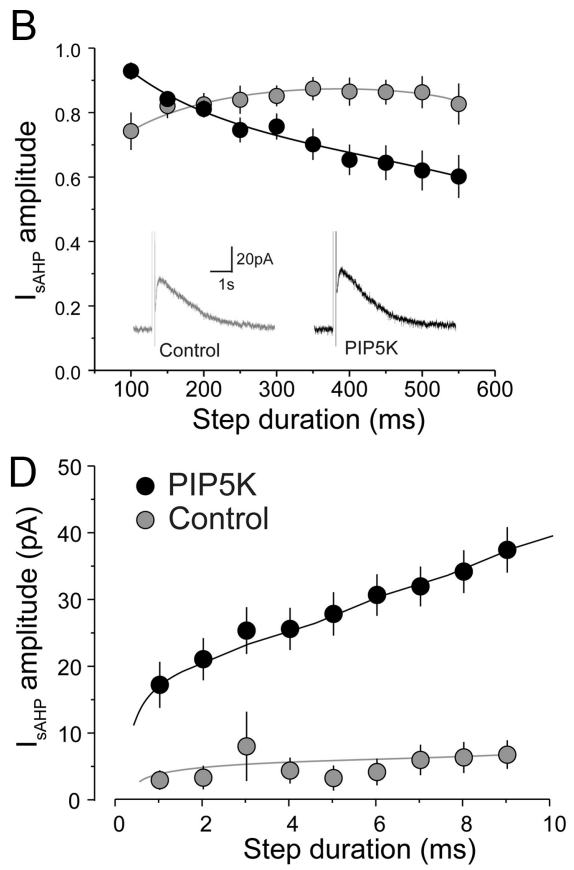

\section{0}

\section{PIP5K}

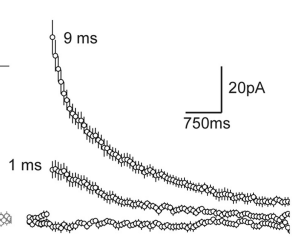

Step duration (ms)

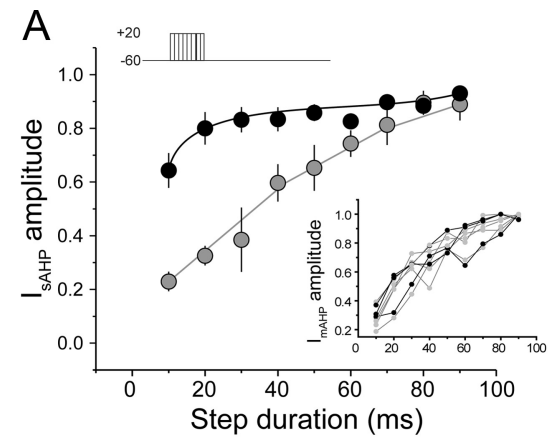

re 7. Expression of PIP5K facilitates the calcium activation of $I_{\text {sAHP. }} A$, Increasing calcium influx using depolarizing steps of (bray) and $n=3$ PIP5K-transfected neurons (black); inset]. $\boldsymbol{B}$, Increasing the duration of the depolarizing steps $\sim 200$ ms has little additional effect on the amplitude of $I_{\text {SAHP }}$ either under control conditions or after transfection with ( (1-10 ms). Under control conditions, such short steps fail to significantly activate $I_{\text {sAHP, }}$ while after transfection with PIP5K they produce robust, graded activations of this current.

potassium current also expressed in these cells. Furthermore, calcium transients imaged at the level of the soma and proximal dendrites did not undergo the dramatic rundown exhibited by $I_{\text {sAHP. }}$. These observations are consistent with results from recent studies showing that depletion of membrane $\operatorname{PtdIns}(4,5) \mathrm{P}_{2}$ is considerably less effective in suppressing high-voltage-activated calcium channel activity than potassium channel activity (Suh et al., 2010). Thus, while neither of these controls alone can completely exclude the possibility that calcium currents rundown could contribute to the rundown of $I_{\mathrm{sAHP}}$, together they make it unlikely that the observed changes in $I_{\mathrm{sAHP}}$ could be explained simply by changes in calcium entry. As such, they support the idea that the functional expression of $I_{\mathrm{sAHP}}$ is directly dependent on the availability of membrane $\operatorname{PtdIns}(4,5) \mathrm{P}_{2}$.

Previous studies have shown that $I_{\mathrm{sAHP}}$ is inhibited by heptahelical receptors coupling to $\mathrm{G} \alpha_{\mathrm{q}-11}$, although the specific mechanisms underlying this effect remain poorly understood (Krause et al., 2002). Here, we show that $5-\mathrm{HT}_{2 \mathrm{~A}}$ receptors, which couple to heterotrimeric G-proteins of the $\mathrm{G} \alpha_{\mathrm{q}-11}$, inhibit $I_{\mathrm{sAHP}}$ in pyramidal cells through a mechanism dependent on the expression of PLC $\beta 1$. Furthermore, we show that the ability of these receptors to inhibit $I_{\mathrm{sAHP}}$ is rendered effectively irreversible upon administration of wortmannin, which can be expected to inhibit resynthesis of PtdIns $(4,5) \mathrm{P}_{2}$, but not of LY 294002, which shares with wortmannin the ability to inhibit PI3K. By analogy with the inhibition of KCNQ channels by muscarinic receptors (Suh and Hille, 2002), we interpret these results to indicate that $5-\mathrm{HT}_{2 \mathrm{~A}}$ receptors, and probably other $\mathrm{G} \alpha_{\mathrm{q}-11}$-coupled heptahelical receptors also expressed in pyramidal cells (Araneda and Andrade, 
1991), inhibit $I_{\text {sAHP }}$ by reducing the availability of membrane $\operatorname{PtdIns}(4,5) \mathrm{P}_{2}$.

Many potassium channels including $\mathrm{K}_{\mathrm{ir}}$ and $\mathrm{K}_{\mathrm{v}} 7$ are directly activated by $\operatorname{PtdIns}(4,5) \mathrm{P}_{2}$, which acts as the "primary agonist" for these channels (Hansen et al., 2011). Could calcium act through PtdIns $(4,5) \mathrm{P}_{2}$ to activate $I_{\mathrm{sAHP}}$ ? In the current work, we tested this possibility by expressing PIP5K, the rate-limiting enzyme for PtdIns $(4,5) \mathrm{P}_{2}$ biosynthesis to increase membrane $\operatorname{PtdIns}(4,5) \mathrm{P}_{2}$. This manipulation did not increase the amplitude of $I_{\text {sAHP }}$, which may have been expected if $\operatorname{PtdIns}(4,5) \mathrm{P}_{2}$ was simply required for the activity of $I_{\text {sAHP }}$ (Hernandez et al., 2009), nor did it occlude $I_{\text {sAHP }}$, which could have been expected if calcium gated $I_{\text {sAHP }}$ simply by increasing overall membrane PtdIns $(4,5) \mathrm{P}_{2}$. Rather, overexpressing PIP5K greatly facilitated the ability of calcium influx to elicit a $I_{\mathrm{sAHP}}$, consistent with the idea PtdIns $(4,5) \mathrm{P}_{2}$ acts downstream but in concert with calcium to activate $I_{\text {sAHP. }}$.

How could Ptdins $(4,5) \mathrm{P}_{2}$ act downstream from calcium to activate the potassium channels whose aggregate activity we record as $I_{\text {sAHP }}$ ? One possibility is that calcium facilitates the ability of PtdIns $(4,5) \mathrm{P}_{2}$ to induce the opening of these channels in a manner perhaps analogous to how $\mathrm{G} \beta \gamma$ activates Kir3.x currents (Huang et al., 1998). Alternatively, previous work has shown that many potassium channels that depend on $\operatorname{PtdIns}(4,5) \mathrm{P}_{2}$ for their activity are subsaturated by resting membrane levels of this phosphoinositide (Du et al., 2004; Delmas and Brown, 2005; Li et al., 2005). Furthermore, it is thought that membrane PtdIns $(4,5) \mathrm{P}_{2}$ is broadly sequestered by "pipmodulins" (McLaughlin and Murray, 2005) and perhaps other mechanisms and that localized calcium rises can "free" PtdIns $(4,5) \mathrm{P}_{2}$ to transiently increase its local availability (Hardie et al., 2001; Musse et al., 2008; Levental et al., 2009). Thus, it is possible that calcium could activate these subsaturated channels by transiently increasing the availability of $\operatorname{PtdIns}(4,5) \mathrm{P}_{2}$. The resulting outward current would then correspond to the aftercurrent we recognize as $I_{\mathrm{sAHP}}$. If this conjecture is correct, $I_{\mathrm{sAHP}}$ would not represent a membrane current carried by a unique class of ion channels but rather the macroscopic manifestation of a biochemical gating mechanism. One attractive feature of this second possibility is that it would explain many of the puzzling properties of this current including its anomalous kinetics and why the $I_{\text {sAHP }}$ channel properties and molecular composition appear to be cell dependent. Future studies will be required to test these conjectures.

\section{References}

Abel HJ, Lee JC, Callaway JC, Foehring RC (2004) Relationships between intracellular calcium and afterhyperpolarizations in neocortical pyramidal neurons. J Neurophysiol 91:324-335.

Akiba Y, Suzuki R, Saito-Saino S, Owada Y, Sakagami H, Watanabe M, Kondo $\mathrm{H}$ (2002) Localization of mRNAs for phosphatidylinositol phosphate kinases in the mouse brain during development. Brain Res Gene Expr Patterns 1:123-133.

Araneda R, Andrade R (1991) 5-Hydroxytryptamine 2 and 5-hydroxytryptamine $1 \mathrm{~A}$ receptors mediate opposing responses on membrane excitability in rat association cortex. Neuroscience 40:399-412.

Béique JC, Imad M, Mladenovic L, Gingrich JA, Andrade R (2007) Mechanism of the 5-hydroxytryptamine $2 \mathrm{~A}$ receptor-mediated facilitation of synaptic activity in prefrontal cortex. Proc Natl Acad Sci U S A 104:9870-9875.

Berg KA, Maayani S, Goldfarb J, Scaramellini C, Leff P, Clarke WP (1998) Effector pathway-dependent relative efficacy at serotonin type $2 \mathrm{~A}$ and $2 \mathrm{C}$ receptors: evidence for agonist-directed trafficking of receptor stimulus. Mol Pharmacol 54:94-104.

Delmas P, Brown DA (2005) Pathways modulating neural KCNQ/M ( $\left.\mathrm{K}_{\mathrm{v}} 7\right)$ potassium channels. Nat Rev Neurosci 6:850-862.

Delmas P, Coste B, Gamper N, Shapiro MS (2005) Phosphoinositide lipid second messengers: new paradigms for calcium channel modulation. Neuron 47:179-182

Du X, Zhang H, Lopes C, Mirshahi T, Rohacs T, Logothetis DE (2004) Characteristic interactions with phosphatidylinositol 4,5-bisphosphate determine regulation of $\mathrm{K}_{\mathrm{ir}}$ channels by diverse modulators. J Biol Chem 279:37271-37281.

Fisher SK, Novak JE, Agranoff BW (2002) Inositol and higher inositol phosphates in neural tissues: homeostasis, metabolism and functional significance. J Neurochem 82:736-754.

Giudici ML, Emson PC, Irvine RF (2004) A novel neuronal-specific splice variant of type I phosphatidylinositol 4-phosphate 5-kinase isoform gamma. Biochem J 379:489-496.

Giudici ML, Lee K, Lim R, Irvine RF (2006) The intracellular localisation and mobility of type Igamma phosphatidylinositol 4P 5-kinase splice variants. FEBS Lett 580:6933-6937.

Hansen SB, Tao X, MacKinnon R (2011) Structural basis of PIP2 activation of the classical inward rectifier $\mathrm{K}^{+}$channel Kir2.2. Nature 477:495-498.

Hardie RC, Raghu P, Moore S, Juusola M, Baines RA, Sweeney ST (2001) Calcium influx via TRP channels is required to maintain PIP2 levels in Drosophila photoreceptors. Neuron 30:149-159.

Hernandez CC, Falkenburger B, Shapiro MS (2009) Affinity for phosphatidylinositol 4,5-bisphosphate determines muscarinic agonist sensitivity of $\mathrm{K}_{\mathrm{v}} 7 \mathrm{~K}^{+}$channels. J Gen Physiol 134:437-448.

Higgs MH, Slee SJ, Spain WJ (2006) Diversity of gain modulation by noise in neocortical neurons: regulation by the slow afterhyperpolarization conductance. J Neurosci 26:8787-8799.

Huang CL, Feng S, Hilgemann DW (1998) Direct activation of inward rectifier potassium channels by PIP2 and its stabilization by Gbetagamma. Nature 391:803-806.

Kim D, Jun KS, Lee SB, Kang NG, Min DS, Kim YH, Ryu SH, Suh PG, Shin HS (1997) Phospholipase C isozymes selectively couple to specific neurotransmitter receptors. Nature 389:290-293.

Krause M, Offermanns S, Stocker M, Pedarzani P (2002) Functional specificity of $\mathrm{G} \alpha_{\mathrm{q}}$ and $\mathrm{G} \alpha_{11}$ in the cholinergic and glutamatergic modulation of potassium currents and excitability in hippocampal neurons. J Neurosci 22:666-673.

Krettek JE, Price JL (1977) The cortical projections of the mediodorsal nucleus and adjacent thalamic nuclei in the rat. J Comp Neurol 171:157-191.

Lasser-Ross N, Ross WN, Yarom Y (1997) Activity-dependent $\left[\mathrm{Ca}^{2+}\right]_{i}$ changes in guinea pig vagal motoneurons: relationship to the slow afterhyperpolarization. J Neurophysiol 78:825-834.

Levental I, Christian DA, Wang YH, Madara JJ, Discher DE, Janmey PA (2009) Calcium-dependent lateral organization in phosphatidylinositol 4,5-bisphosphate (PIP2)- and cholesterol-containing monolayers. Biochemistry 48:8241-8248.

Lev-Ram V, Miyakawa H, Lasser-Ross N, Ross WN (1992) Calcium transients in cerebellar Purkinje neurons evoked by intracellular stimulation. J Neurophysiol 68:1167-1177.

Li Y, Gamper N, Hilgemann DW, Shapiro MS (2005) Regulation of $\mathrm{K}_{\mathrm{v}} 7$ (KCNQ) $\mathrm{K}^{+}$channel open probability by phosphatidylinositol 4,5bisphosphate. J Neurosci 25:9825-9835.

Li Y, Zaydman MA, Wu D, Shi J, Guan M, Virgin-Downey B, Cui J (2011) KCNE1 enhances phosphatidylinositol 4,5-bisphosphate (PIP2) sensitivity of IKs to modulate channel activity. Proc Natl Acad Sci U S A 108:9095-9100.

Logothetis DE, Jin T, Lupyan D, Rosenhouse-Dantsker A (2007) Phosphoinositide-mediated gating of inwardly rectifying $\mathrm{K}^{+}$channels. Pflugers Arch 455:83-95.

McLaughlin S, Murray D (2005) Plasma membrane phosphoinositide organization by protein electrostatics. Nature 438:605-611.

Meech RW (1978) Calcium-dependent potassium activation in nervous tissues. Annu Rev Biophys Bioeng 7:1-18.

Meyers R, Cantley LC (1997) Cloning and characterization of a wortmanninsensitive human phosphatidylinositol 4-kinase. J Biol Chem 272:4384-4390.

Musse AA, Gao W, Homchaudhuri L, Boggs JM, Harauz G (2008) Myelin basic protein as a "PI $(4,5) \mathrm{P}_{2}$-modulin": a new biological function for a major central nervous system protein. Biochemistry 47:10372-10382.

Nakanishi S, Catt KJ, Balla T (1995) A wortmannin-sensitive phosphatidylinositol 4-kinase that regulates hormone-sensitive pools of inositolphospholipids. Proc Natl Acad Sci U S A 92:5317-5321.

Nicoll RA (1988) The coupling of neurotransmitter receptors to ion channels in the brain. Science 241:545-551. 
Pennefather P, Lancaster B, Adams PR, Nicoll RA (1985) Two distinct Cadependent K currents in bullfrog sympathetic ganglion cells. Proc Natl Acad Sci U S A 82:3040-3044.

Rohacs T (2009) Phosphoinositide regulation of non-canonical transient receptor potential channels. Cell Calcium 45:554-565.

Rohacs T, Lopes C, Mirshahi T, Jin T, Zhang H, Logothetis DE (2002) Assaying phosphatidylinositol biphosphate regulation of potassium channels. Methods Enzymol 345:71-92.

Sah P, Faber ES (2002) Channels underlying neuronal calcium-activated potassium currents. Prog Neurobiol 66:345-353.

Schwindt PC, Spain WJ, Foehring RC, Stafstrom CE, Chubb MC, Crill WE (1988) Multiple potassium conductances and their functions in neurons from cat sensorimotor cortex in vitro. J Neurophysiol 59:424-449.

Schwindt PC, Spain WJ, Crill WE (1992) Calcium-dependent potassium currents in neurons from cat sensorimotor cortex. J Neurophysiol 67:216-226.

Stauffer TP, Ahn S, Meyer T (1998) Receptor-induced transient reduction in plasma membrane PtdIns $(4,5) \mathrm{P}_{2}$ concentration monitored in living cells. Curr Biol 8:343-346.

Stocker M, Hirzel K, D'hoedt D, Pedarzani P (2004) Matching molecules to function: neuronal $\mathrm{Ca}^{2+}$-activated $\mathrm{K}^{+}$channels and afterhyperpolarizations. Toxicon 43:933-949.

Stoppini L, Buchs PA, Muller D (1991) A simple method for organotypic cultures of nervous tissue. J Neurosci Methods 37:173-182.

Suh BC, Hille B (2002) Recovery from muscarinic modulation of M current channels requires phosphatidylinositol 4,5-bisphosphate synthesis. Neuron 35:507-520.

Suh BC, Inoue T, Meyer T, Hille B (2006) Rapid chemically induced changes of PtdIns $(4,5) \mathrm{P}_{2}$ gate KCNQ ion channels. Science 314:14541457.

Suh BC, Leal K, Hille B (2010) Modulation of high-voltage-activated $\mathrm{Ca}^{2+}$ channels by membrane phosphatidylinositol 4,5-bisphosphate. Neuron 67:224-238

Tzingounis AV, Nicoll RA (2008) Contribution of KCNQ2 and KCNQ3 to the medium and slow afterhyperpolarization currents. Proc Natl Acad Sci U S A 105:19974-19979.

Tzingounis AV, Kobayashi M, Takamatsu K, Nicoll RA (2007) Hippocalcin gates the calcium activation of the slow afterhyperpolarization in hippocampal pyramidal cells. Neuron 53:487-493.

Villalobos C, Andrade R (2010) Visinin-like neuronal calcium sensor proteins regulate the slow calcium-activated afterhyperpolarizing current in the rat cerebral cortex. J Neurosci 30:14361-14365.

Villalobos C, Shakkottai VG, Chandy KG, Michelhaugh SK, Andrade R (2004) SKCa channels mediate the medium but not the slow calciumactivated afterhyperpolarization in cortical neurons. J Neurosci 24: $3537-3542$.

Villalobos C, Béique JC, Gingrich JA, Andrade R (2005) Serotonergic regulation of calcium-activated potassium currents in rodent prefrontal cortex. Eur J Neurosci 22:1120-1126.

Vogalis F, Storm JF, Lancaster B (2003) SK channels and the varieties of slow after-hyperpolarizations in neurons. Eur J Neurosci 18:3155-3166.

Volpicelli-Daley LA, Lucast L, Gong LW, Liu L, Sasaki J, Sasaki T, Abrams CS, Kanaho Y, De Camilli P (2010) Phosphatidylinositol-4-phosphate 5-kinases and phosphatidylinositol 4,5-bisphosphate synthesis in the brain. J Biol Chem 285:28708-28714.

Watanabe M, Nakamura M, Sato K, Kano M, Simon MI, Inoue Y (1998) Patterns of expression for the mRNA corresponding to the four isoforms of phospholipase Cbeta in mouse brain. Eur J Neurosci 10:2016-2025.

Williams SL, Lutz S, Charlie NK, Vettel C, Ailion M, Coco C, Tesmer JJ, Jorgensen EM, Wieland T, Miller KG (2007) Trio's Rho-specific GEF domain is the missing $\mathrm{G} \alpha_{\mathrm{q}}$ effector in C. elegans. Genes Dev 21:27312746.

Yan HD, Villalobos C, Andrade R (2009) TRPC channels mediate a muscarinic receptor-induced afterdepolarization in cerebral cortex. J Neurosci 29:10038-10046

Zhang H, Craciun LC, Mirshahi T, Rohács T, Lopes CM, Jin T, Logothetis DE (2003) PIP ${ }_{2}$ activates KCNQ channels, and its hydrolysis underlies receptor-mediated inhibition of M currents. Neuron 37:963-975. 